Vol. 4, No. 1, 2017

УДК 273 (73)“1884-1914”

\title{
FORMATION OF GREEK CATHOLIC CHURCH ORGANIZATIONAL STRUCTURE IN UNITED STATES: PARISHES AS CENTERS OF NATIONAL AND CULTURAL LIFE OF UKRAINIAN EMIGRATION (1884-1914)
}

\author{
Iryna Hnidyk \\ Institute of Humanities and Social Sciences \\ Lviv Polytechnic National University
}

\section{() Hnidyk I., 2017}

The study focus is given to the initial stage of formation of Greek Catholic Church in the United States. Certain common features, peculiarities, difficulties and conditions of parishes forming process are analysed. New criteria for more complete study are suggested in view of the historiography problem of parishes establishment dating. The statistics, geography, dates and dynamics of main parishes, general amount of churches, priests and parishioners are explored in the paper on the basis of historical sources.

Key words: Greek Catholic Church, parish, priest, development, community, emigrants, establishment.

Досліджено початковий етап становлення Греко-Католицької Церкви у США. Проаналізовано загальні риси, особливості, труднощі та обставини процесу організації парохій. Характерно, що нові парохіяльні осередки створювалися доволі швидко. Цей процес зумовлений широкими територіальними межами розселення української еміграції. Відповідно, кожна група прагнула мати свою парохію, оскільки добиратися до найближчої в іншому містечку було доволі складно. 3 огляду на історіографічні розбіжності щодо датування організації парафій та будівництва церков запропоновано додаткові критерії для комплекснішого дослідження зазначеної проблематики. Особливу увагу звернено на статистику, географію, хронологію та динаміку процесу організації головних парафій, загальну кількість церков, священиків та парохіян упродовж різних етапів. Здійснено порівняльну характеристику на основі наявної історіографії та архівних джерел, які дають змогу реконструювати особливості діяльності парохіяльних осередків та головні організаційні проблеми.

Ключові слова: Греко-Католицька Церква, парохія, священик, організація, емігранти.

The problem setting. Foundation of the first Greek Catholic parish in the United States in December, 1884 initiated the religious, national and social development of Ukrainian emigration community. Shenandoah, Virginia became the first, but not the only, Greek Catholic Church community organizational center. Ukrainian emigrants from territories near and far asked priest Ivan Volyansky to celebrate the liturgy and to help with the organization of new parish. Chronologically, parallel pastoral activities of I. Volyansky in other emigrant towns were concurrant with the active church building in Shenandoah (1885). Therefore, in addition to their pastoral work in Shenandoah, priests began actively organize churches in Jersey City, Minneapolis, Kingston, Freeland, Olyphant, Shamokin, and Wilkes-Barre, among others [4, p. 7].

The results of the study. The initial stage of Greek Catholic Church formation in United States is characterized by certain common features. First of all, these are the significant territorial boundaries of the first parishes, which provided the religious needs of Ukrainian emigrants from a large number of nearby settlements. Since main parishes churches could not accommodate the demand, and in view of the difficulty of long distance travel, smaller church communities were founded [17, p. 97]. Very often one priest took care of several parish centers in considerable distance from each other, what caused a lot of difficulties. In addition, the constant problem was the lack of Greek Catholic priests [27, p. 27], as evidenced by the archival and statistical data. "We have constant need in our priests..." [28, p. 10] - priest Illyia Kuziv noted in a letter from United States.

The process of parishes foundation usually started with general meetings of local emigrants united into a single community. After that, they compiled an estimated cost, determined the amount of each member's contribution, searched for a plot of land, and reached agreements with the architect and builders. "People add up their savings and buy a plot of land for church building at high price. Suddenly lacking in conscientious contractor rushes and builds a chapel allegedly at price $\$ 600$ but after construction will add more than $\$ 200$ to its price [...] So, the general price of church building is more than $\$ 2000$ ” [23, p. 1]. Regarding cost and architectural design of Greek Catholic churches in United States there are three stages clearly seen in most parishes. At first Greek-Catholic communities built small wooden 
churches costing from $\$ 3,000-\$ 8,000$. Intended church construction intended the inclusion of the three domes found in the emigrants' homeland, but builders often did a poor work, which resulted in incorrectly formed domes which more closely resembled traditional Orthodox churches. Therefore, architects began to build churches either in Gothic, Romanesque or mixed styles. Depending on the growth of the parishes, there was a need for the construction of larger stone churches. The price of these structures was $\$ 15,000$ - $\$ 40,000$. Later, the tendency was for the construction of more majestic churches costing $\$ 60,000-\$ 100,000)$. A peculiarity of the building was the obligatory hall for parish congregations and schools [16, p. 262-265]. An important issue was parish community's legal registration and preparation of statutes.

Unlike Western Ukrainian lands, the community of the laity, which actually held the church financially, was actively involved in church life in the United States. Therefore they claimed a significant authority and awareness in church administration. Thus a peculiar phenomenon called "lay trusteeism" was originated, which was expressed by the active control of the laity in church affairs. This situation was completely unknown for American Catholic hierarchy [5, p. 30]. Prior to the first bishop arrival in 1907 church property was registered to parish council - trustees. However, the laity committees often didn't hurry to re-register ownership for their bishop, as it was supposed to do. There were sharp controversies and splits. This process is absolutely American forming in the lives of Ukrainian settlers. The wish to lead church life came not from piety and altruistic considerations, but from the personal ambitions of several of the most active lay businessmen. "[...] Every person wants to be principal, everyone wants to have more rights to the church than the other, because he also invested his own cent and worked in building more than others" [23, p. 1]. They aspired to take a dominant position in the community life. This situation often led to negative consequences in parish life and caused difficulties for the priests. The parish councils aspired to receive all information about Church management. Otherwise they actively expressed dissatisfaction and demanded detailed information about church affairs [12, p. 32-33]. Ruling leaders expressed their own views on this subject in magazines and were not always moderate in their criticisms. Due to the frequent arguments arising from these circumstance, priests had to overcome many obstacles. "It seems to me that there is no more unlucky man in America than our priest. A lot of nonsense made by our people is necessary to bear and mishear, because one enemy can cause a lot of disaster" [28, ark. 13] noted about it priest Illyia Kuziv.

Another peculiarity concerns chronological data. Dates of parishes establishment often do not coincide with dates of the first churches constructed in these territories. Like in Shenandoah, the first liturgies were held in tenements. Taking into consideration this fact it is expedient to take two criteria for dating: first of all, the date of parish foundation (from the moment of the First Divine Liturgy) and the date of church construction completion. In addition, for a more complete study of the dynamics of the development of Greek Catholic parishes in the United States, it is worthwhile to highlight additional dating aspects: the establishment of church fraternities that assumed responsibility of fundraising for the church construction; the purchase of land; the blessing of the cornerstone and new church buildings. The establishment of various church associations, parish choruses, schools shows the cultural and educational activities. It is also necessary to take into consideration that regardless of a church's construction state the Divine service was frequently held in rented premises. Therefore, it would be wrong to start parish history from the date of church construction. According to this situation, there are many historiographical differences regarding these dates, just as with the dating of the parish in Shenandoah. That's why this problem requires a comprehensive study and comparison of dates based on sources and historiography.

Due to the growing number of emigrant parishes over a relatively short period of time, subsidiary churches were built on the model of these early churches.] In particular, the parish in Shenandoah was divided twice: in 1886, when one part became a parish of the Transfiguration in Shamokin and in 1908, when the parish of St. John the Baptist in Miesville was created [17, p. 97].

At the foundation of the parish in Shamokin, there were 100 parishioners. Before the arrival of the first Greek Catholic priest they visited local Polish churches. Subsequently, the community appealed to I. Volyansky with a request to establish a parish. The first Liturgies were held in private houses and in the local school hall. In view of the growing number of emigrants, church construction process began [26, p. 3]. In order to organize the fundraising a brotherhood of St. Cyril and Methodius was established in May, 1888. A land plot was purchased in November (for \$400). The cornerstone was consecrated by I. Volyansky, and on September 22, 1889 priest K. Andrukhovych performed the solemn consecration of the church. Since 1888 metric books have recorded baptisms, marriages and funerals. The property was officially registered to the Brotherhood of St. Cyril and Methodius [281]. Functions of the priest in 1886-1888 were performed by I. Volyansky. Other priests included, Theofan Obushkevych (1890-1891), who moved to Olifant, Cornelius Lavryshyn (1892-1893), and Ivan Konstankevych (1893-1918) [31, p. 96-97]. During the activity of the latter, a house for the priest and a plot under the cemetery were bought. In 1894 the first parish church choir was founded [14]. These dates coincide in researchers works, while the following new church buildings dates need to be clarified. In 1898 the construction of a brick church with the parish hall began. The modern building was completed on October 29, 1907, the parish home in 1908, and the monastery in 1911 [17, p. 96- 
97]. In 1903, in order to care for the sick and dying in the parish, the Society of St. Anna was established. Materials from the site of the modern church in Shamokin provide different dates that do not coincide with the previous dating (the construction of the next church structure according to their version began in 1904 and ended the next year. Perhaps it is a matter of detailing of building dating criteria or of false sources.

During 1886-1887 parishes were established in Freeland, Gazelton and Kingston (Pennsylvania) [24]. The latter was a key establishment. The consecration of the church was carried out on October 30 by the priests I. Volyansky and Zenon Liakhovich. By this time, Greek Catholic worship took place just like in other places, in the home of parishioner Stephan Barniy, where a temporary chapel was organized. Z. Lyakhovych was appointed as the priest, but on November 4 , he died because of a heart attack and was succeeded by Mykola Zubrytsky, who only stayed for a short period. I. Volyansky had to head the parish until the arrival of Kostyantyn Andrukhovych, whose term was also short, lasting until June 1889 [20, p. 6-7]. On May 16, 1892, the church was named after the Protection of the Virgin. Shortly thereafter, three Greek Catholic churches were founded in the surrounding area: St. Peter and Paul church (Plymouth) in 1898, St. Nicholas church (Swidersville) in 1904 and St. Volodymyr church (Edwardsville) in 1910 [1].

The church in Kingston was rebuilt twice. On July 4, 1911 a cornerstone to the construction of a larger church was dedicated (the previous building became a parish hall). The modern building dates back to 1972 . In parallel with the parish in Kingston, the formation of the Greek Catholic community in Wilkes-Barre, Pennsylvania and Jersey City, New Jersey, took place. In Wilkes-Barre the church cornerstone was consecrated on August 28, 1887. On April 6, 1889 the church in honor of the Assumption of the Blessed Virgin was blessed. The priest Alexander Dzyubay arrived as a result of the appeal of parishioners to Mukachevo Bishop Yulian Firtsak. Almost all Greek Catholics in Wilkes-Barre came from Transcarpathia. The current church at 695 Norz Maynne Street was consecrated on September 6, 1900 by the next priest Kornylo Ilyashevych [20, p. 7]. Although, the official website of the modern church in Wilkes-Barre provides another date, spring of 1907, when new building construction began, lasting a year. There is a similar discrepancy of a year with the dating of the dedication of the cornerstone. As in the case of dating of the first church construction in Shenandoah, additional research and comparison of the dates of various researchers and sources is required. In 1909, on the instructions of Bishop Stephan Soter Ortynsky, a priest Illyia Kuziv came here. He had developed a draft church statute. The next priest was his brother Mykhailo Kuziv who was appointed on June 11, 1911. As a source of more information about this parish activity are letters of both priests to Metropolitan Andrey Sheptytsky, which are stored in the funds of the Central State Historical Archive in Lviv [28].

The Jersey City Greek-Catholic Parish covered New Jersey, New York City and the neighborhood. In these territories there were rather high prices for land plots comparing with the previous ones. Because of it the formation of the parish was rather difficult for emigrants in the financial plan. On arriving in America I. Volyansky stopped just in Jersey City and even planned to stay here. However, it did not happen but in 1887 he visited a community of Ukrainian emigrants, which consisted of about 17 families, mostly Galicians. In the "First Ruthenian American Calendar" this parish was named the oldest in the United States [20, p. 9-10]. At the beginning, here was the priest I. Volyansky (1887), after him Kostyantyn Andrukhovych (1887-1889) [17, p. 58]. All church property, like in other parishes, was registered to I. Volyansky and his wife, what later became the cause of misunderstandings. In 1887 a wooden chapel was built in the corner of Henry and Chestnat Street. The next construction of the church began by priest Hryhoriy Hrushka in the autumn 1891. In the spring 1892 the church was consecrated in the presence of the large number of emigrants and Greek Catholic priests. Subsequently, the parish was divided six times. Jersey City was one of the first centers of the transition of Greek Catholics to Orthodoxy in period of priests H. Hrushka (1889-1896) and Ivan Ardan (1896-1897). After him the church committee of 12 people who were re-elected each year headed the parish life [20, p. 10]. In 1898-1905 the parish was administered by priest Mykola Pidgoretsky, in 1906-1908 by Alexandr Humetsky and in 1908-1925 by Olexandr Ulytsky [17, p. 78].

In Olyfant a wooden church-chapel was built in 1888 due to the efforts and financial support of emigrants. At the time of foundation, there were 800 parishioners. It is interesting that the permanent records of baptism, marriages and funerals have been kept in the parish since 1891, while the registration of the first Solemn Communion - from 1948 [17, p. 78]. In 1891, in view of the growth of the parish, the church building was expanded [20, p. 8]. In 1893 the residence of the priest was completed. The modern church building was erected in 1908-1910. The priests during the investigated period were: I. Volyansky (1888-1890), Havryil Vyslotsky (1891), Teophan Obushkevych (1891-1897), Ivan Ardan (1897-1902), Mykola Strutynsky (1902-1905), Ivan Velygorsky (1905-1906), Volodymyr Stack (1906), Hryhoriy Vasovych (1906-1907), Alexander Ulytsky (1907), Volodymyr Stek (1906 p.), Hryhoriy Vasovchyk (19061907), Oleksandr Ulytskyi (1907), Vasyl Hryvnyak (19081909), Ivan Sendetskyi (1910-1911), Illyia Kuziv (19111915) [31, p. 770].The parish was one of the key emigrant churches and often attracted attention. "Here in Olyphant people are haughty and proud, because there are many people of estate, therefore the position of the priest is more difficult" [28, ark. 13] - outlined priest I. Kuziv.

In the spring 1889, Blessed Virgin Mary Protection Church in Minneapolis (Minnesota) was consecrated. However, since 1878, Ukrainian emigrants from Transcarpathia (Beherov, Komlosh and Stebnyk) resided there. As of 1884 there were about 80 of them. 
Before the arrival of I. Volyansky spiritual ward over them was carried out by Polish priest Jan Pakholsky. The first Greek Catholic Liturgy in Minneapolis was performed by I. Volyansky in the house of Pavlo Podanyi and Yuriy Gomzyk. Like Jersey City, this parish was influenced by Orthodoxy during the pastoral activity of priest from the Diocese of Pryashiv Olexiy Tovt. The main reason of transition was the biased attitude of the American Archbishop J. Airland, who did not allow O. Tovt to perform priestly duties [20, p. 10-11].

As of 1889 in the United States there were already six Greek Catholic churches [6, p. 23-24]. In June this year, considering the American episcopacy opposition, I. Volyansky was forced to leave the United States. He passed the administration of parish affairs and the church treasury to K. Andrukhovych, the priest in Kingston.

During 1889-1890 parishes were founded in Whiting (Indiana), Passaic (New Jersey) and Ducktwen (West Pennsylvania) [24; 10]. In 1891 the Blessed Virgin Mary Protection parish was founded in the city of Mecady. Its primary area was Gonay Brook, Yorktown, Carbon County, Silver Brook, Pleasant Hill, Trescow, and Mecady. The first church building was, as in previous parishes, wooden, brick one was built in 1907. In 1910 a parish home was constracted. At the time of foundation there were 1,000 parishioners. In 1896 a church choir was created. The first priest was K. Andrukhovych (1892-1894) [17, p. 65-66].

In 1892, the parish was organized in Leisenring with the help of priest Olexandr Dzyubay, who came here from Wilkes-Barre. Thanks to the active work of the parish committee of twelve people, funds were raised for the construction of the church. In this process they received help from "H.C. Frick Coke Co. in Scottdale", which donated 12 acres of land and \$25 monthly aid. Construction was completed the same year, before that the Liturgies were carried out at the house of parishioner. Greek Catholics came to the newly built St. Stephan church from the surrounding territories, overcoming several kilometers concerning the lack of public transport. Several years later, new parishes were organized and new churches were built in these territories Charleroi, Monessen, Uniontown, Perryopolis, New Salem, Brownsville, Scotland and Troger (Latrobe) [9].

In 1893, parishes were established in Mount Carmel and in Punxsutawney [17, p. 30]. The latter town was the center of nearby mining communities. The parish united communities from Walston and Adrian. There was a large number of emigrants from the territories of Austria-Hungary. They were united together by the priest Ivan Sabo with aim of Greek-Catholic parish establishing. Two local entrepreneurs S. Keltonik and Robinson from "Rochester and Pittsburgh Coal Company" had helped them. The latter helped community to rent a hall where the Liturgies were performed for almost a year. A major obstacle was a great strike of the coal industry workers in 1894. On
May 12, 1895, a cornerstone was dedicated, and on July 4th - a wooden church was consecrated by Eugen Volkay, priest from Brooklyn. The parish was constantly growing, and in 1904 there was need for a larger church construction. The church was projected according to the model of the famous Hungarian shrine of the Virgin Mary in the city of Maryapoc (Máriapócs). The construction contract was signed $\$ 1,500$ in total. On August 4, 1905, the church was solemnly dedicated by Apostolic Visitator Andriy Godobay [11].

In 1894, the parishes in Glen Lyon, Troger (now Latrobe) [24] and others were founded. According to statistical data during this period in the United States there were 26 priests from Transcarpathia and 6 from Galicia with 100 thousand parishioners [6, p. 24]. Over the next two years, parishes were established in Alden Station, (the church was purchased as early as in 1918), Elmira Heights (New York), Johnstown, Minersville, Braddock [17, p. 30, 39, 69] etc.

At the period from 1897 to 1907, parishes were founded in Mangol (Pennsylvania), Marblehead (Ohio), Troy (New York), Ansonia (Connecticut), Denver, Nanticoke (Pennsylvania), Plymouth, Barnesboro, Pennsylvania (now Northern Cumbria), Providence City (Ohio), Charleroi, Jonkers (New York), Northampton (visited by Ukrainians living in Bethel), Pittsburgh-South Side, Windber (Pennsylvania), Youngstown (Ohio), Carnegie, Wilmington, Elizabeth, Simpson, Fairfield, Ford City, Chicago [29, p. 38], Saint Clair, Reading, Wilton, Newark, Detroit, Berwick, St. Louis, Saukville, Jefferson, South Fork [24; 17, p. 30-190; 19, p. 1; 22, p. 1], (Nanticoke - new parish), Perth Amboy (New Jersey). In the letter of priest Constantyn Kurylo (dated October 6, 1907) the information about Perth Amboy parish survived: "[...] has already been bought a church, Ruthenian families are 300, a large city, factory, over the sea, the air is pretty good. People here are not corrupted by anyone, and the work [...] is good and I remain here for a few months, but I do not organize the whole parish, but I want to open an exemplary school" [30, p. 4].

During the initial period of Greek Catholic Church formation in the United States, there was a positive rapid dynamics of new parishes creation. At the end of 1898 in the United States there were 51 churches. As of 1905, according to the statistics of the Congregation for the Propagation of Faith, based on the report of the Apostolic Delegate D. Falconio, there were already 84 parishes with 81 priests (49 married, 9 widows, 15 celibates and 8 monks) [21, p. 141].

On March 26th, 1907 thanks to the efforts the Metropolitan Andrey Sheptytsky [15, p. 87] Pope Pius X appointed the Basilian monk, Stephan Ortynsky (monastic name - Soter), a bishop for Greek Catholics in the United States. On May 12 an ordination of S. Ortynsky took place at St. George Cathedral in Lviv. After that the newly appointed bishop visited Pope Pius 
X. Also S. Ortynsky arrived to Vienna and Budapest with aim to meet with representatives of the Austrian government. He also visited the Transcarpathian bishops in Uzhhorod and Pryashiv. These were important visits, since the Transcarpathian settlers made up a significant part of Ukrainian emigration in the United States [3].

In August, 1907 Ukrainian emigrants began an active preparation for a meeting with the bishop. Each issue of Ukrainian magazine "Svoboda" published in the USA informed about new details of the organization of celebrations. The bishop arrived to the United States on August 27. He was met by Galician and Transcarpathian priests in the port of Hoboken. The prayer and greetings of the bishop occurred in St. George church in New York. In the evening a gala dinner took place at the Nederland Hotel [18, p. 33-34]. Since the arrival of S. Ortinsky a new stage of the Greek Catholic Church development in United States began [8, p. 154].

During the period of S. Ortinsky's bishopric there was also an active dynamics of new parishes creation. A feature of this stage is the participation of bishop in the consecration of churches and active visitation of parishes [27, p. 26]. In 1908, Greek Catholic parishes appeared in Chester, Maysville, Scranton, Madison, and others. In 1909, the parishes were founded in Seyr, Hazleton, Wilkes-Barre, Cleveland [17, 48-191]. Currently, there are about 140 churches in the United States (most in the eastern states: Pennsylvania - 80, New York -14 , Ohio -12 , New Jersey -10 ) and approximately 112-118 priests (62 from Transcarpathia, 64 in marriage, 23 widows, 25 celibates) [13, p. 116]. In 1910, the first cathedral in Philadelphia was consecrated, parishes were established in Edwardsville, Middleport, Passaic, Chicago, Johnstown, New York (the future St. George Church). During the period 1911-1914, the parishes were created at Clifton Heights, Marion Heights, Arnold, Minneapolis, Bethlehem (the community was going to worship at the basement chapel of the Irish Roman Catholic Church), Hamtramck, Baltimore, Curtis Bay; Philadelphia (Frankford) [17, p. 37-195], etc. As of 1913 , there were about 150 priests, 152 parishes and about 500,000 faithful $[6$, p. $35 ; 5$, p. $129 ; 12$, p. 104].

Results. Thus, the formation of the organizational structure of Ukrainian Greek Catholic Church in United States took place during the years 1884-1914. Characteristically, the new parish centers appeared quite quickly, bringing together more and more emigrants everywhere. This tendency set the urgent need for the appointment of a separate bishop for the Greek Catholics. After S. Ortynsky nomination in 1907 a new stage of church development began. During his bishopric period, solutions of main problems of organizational development of Ukrainian Greek Catholic Church in the United States took place.

1. Brief History of St. Mary's Byzantine Catholic Church, Kingston, PA. [Електронний ресурс]. - Режсим доступу: // http://www.oocities.org/ pgresh/served.html // 05.02.14. 2. Kaszczak I. The Ukrainian Catholic Church in America: the first forty years (1884-1924 ) / Ivan Kaszczak // The Ukrainian Quarterly. - 2008. - No. 3-4. - P. 200-210. 3. Krawczeniuk O. Origin of the Ukrainian Church in America / O. Krawczeniuk [Електронний ресурс]. - Режсим доступу: http: // theology.in.ua/en/index/monitoring/ society_digest/ 61631// 17.10.14. 4. Kuropas M. The rest of the story // The Ukrainian Weekly. - 2006. - October, 1. - P. 7. 5. Paska W. Sources of Particular Law for the Ucrainian Catholic Church in the United States: A Dissertation Submitted to the Faculty of the Scool of Religious Studies of the Catholic University of America / Walter Paska. - Washington, 1975. - 183 p. 6. Pospishil V. J. Ex occidente lex. From the West - the law. The Eastern Catholic Churches under the tutelage of the Holy See of Rome /V. J. Pospishil. - N. Y. : St. Mary's religious action fund, 1979. - 164 p. 7. Procko B. The Byzantine Catholic Province of Philadelphia: A History of the Ukrainian Catholic Church in the U.S.A. Dissertation presented to the Faculty of Arts of the University of Ottawa throughthe Department of History as partial fulfillment of the requirements for the degree of Doctor of Philosophy / B. Procko. - Villanova, 1963. 8. Procko B. The establishment of the Ruthenian Church in the United States, 1884-1907 / Bohdan Procko // Pennsylvania history. - 1975. - 42. - P. 154. 9. Saint Stephen Byzantine Catholic Church Leisenring, PA. History [Електронний ресурс]. - Режим docmyny: http://www.archpitt.org/ component/ zoo/item/leisenringpa // 25. 05. 13. 10. Saints Peter and Paul Byzantine Catholic Church [Електронний ресурс]. - Режим docmyny: http://home.catholicweb.com/ ByzantinePunxy/ index.cfm/about // 02. 06. 14. 11. Saints Peter and Paul Byzantine Catholic Church Duquesne, PA History [Електронний ресурс]. Режим docmyny: http:// www.archpitt.org/component/ zoo/ item/duquesnepa 12. Slivka J. Historical Mirror Sources of the Rusin and Hungarian Greek Catholics in USA, 1884-1963 / J. Slivka. - Brooklyn, N. Y., 1978. - 342 p. 13. Warzeski W. Byzantine Rite Rusins in Carpatho-Ruthenia and America / Walter Warzeski. - Pittsburgh: Byzantine Seminary Press, 1971. - 332 p. 14. Worth Parish history (1884-2010) // [Електронний ресурс]. Режим docmyny: http://www.transfigurationchurch shamokin.com/history.htm125 // 19.05.14. 15. Баб'як А. Подвиг Митрополита Андрея Шептищького як Апостольського візитатора для українців (1920-1923) $i$ його взаємини з урядом Польщі / Августин Баб'як. - Тренто-Больиано, 2013. c. 2. 16. Бачинський Ю. Украйнська імміграиія в 3'єдинених держсавах Америки / Юліан Бачинський. - Т. 1. - Львів, 1914. 492 с. 17. Блажейовський Д. Берестейська ре-унія та українська історична доля і недоля. Т. II: Київька Вселенська Церква в діаспорі (1751-1988) / Пер. з англ. - Львів: Свічадо, 2000. - 1148 c. 18. Ваврик В. Спископ Сотер Ортинський Чина Святого Василія Великого. У сорокаліття його смерти / Василь Ваврик. - Філадельфія : Видавниитво ОО. Василіян у ЗДА, 1956. - 75 с. 19. Відозва до всіх відділів Р. Н. Союза // Свобода (США). - 1907. - 26 вересня. - С. 1. 20. Кравченюк O. Стеэнками Отия Івана Волянського в Америиі / Осип Кравченюк. - Йорктон, 1981. - 85 с. 21. Мудрий С. Перехід на інший обряд (з візантійсько-украӥнського на латинський) / Софрон Мудрий / пер. з латинської мови о. Івана Козовика. Жовква : Місіонер, 2013. - 228 с. 22. На обезпеченіе издержекъ привитанія его Преосв. С. Сот. Ортиньского новейше жертвовали // Свобода (США). - 1907. - 15 серпня. С. 1. 23. Не будуйте каплииь! // Свобода (США). - 1896. 9 липня. - С. 1. 24. Офіційний сайт Русинської ГрекоКатолищької архиєпархї Пітсбургу [Електронний ресурс]. Режим доступу: http://www.archpitt.org/ // 24.01.14. 25. Прощяанє Ексиелениії Андрея Шептицького // Свобода 
(США). - 1910. - 8 грудня. - С. 1. 26. Спомини з давних літ // Свобода (США). - 1912. - 5 вересня. - С. 4. 27. Центральний державний історичний архів Украйни у м. Львові ((ЦДІАЛ України), ф. 358 (Шептицький Андрей (Роман-МаріяОлександр) (1865-1944), митрополит Галищький грекокатолищької Церкви, граф), оп. 2, спр. 151 (Листи священика Ермі Кароля з Канади і США до Шептичького А.), 105 арк. 28. ЦДІАЛ Украӥни, ф. 358 (Шептичький Андрей (РоманМарія-Олександр) (1865-1944), митрополит Галищький греко-католищької Церкви, граф), оп. 2, спр. 178 (Листи священиків Кузіва Іллі $i$ Михайла до Шептицького А.), 61 арк. 29. ЦДІАЛ України, ф. 358 (Шептицький Андрей (Роман-Марія-Олександр) (1865-1944), митрополит Галицький греко-католицької Церкви, граф), оп. 2, спр. 85 (Листи кореспондентів з прізвищами на літери «Б-Я» зі США до Шептииького А.), 97 арк. 30. ЦДІАЛ України, ф. 358 (Шептицький Андрей (Роман-Марія-Олександр) (18651944), митрополит Галищький греко-католищької Церкви, граф), оп. 2, спр. 86 (Листи священика Курилло Костянтина 3 США до Шептицького А.), 125 арк. 31. ЦДІАЛ Украӥни, ф. 358 (Шептииький Андрей (Роман-Марія-Олександр) (1865-1944), митрополит Галищький греко-католищької Церкви, граф), оп. 2, спр. 230 (Листи священиків Оруна Захара і Підгорецького Миколи з Нью-Йорка до Шептицького А.), 37 арк. 32. ЦДІАЛ України, ф. 789 (Пристай Олекса (1863-1944), греко-католищький священик, місіонер у США, иерковний $i$ громадський діяч), оп. 1, спр. 7 (Спогади про місіонерську діяльність в Америщі, листування $з$ Бачинським М., Охримовичем В., Шептичьким А. та ін.), 151 арк.

\section{References}

1. Brief History of St. Mary's Byzantine Catholic Church, Kingston, PA. [Електронний ресурс]. - Режим docmyny: http://www.oocities.org/ pgresh/served.html // 05.02.2014. 2. Kaszczak I. The Ukrainian Catholic Church in America: the first forty years (1884-1924) / Ivan Kaszczak // The Ukrainian Quarterly. - 2008. - No. 3-4. - P. 200-210. 3. Krawczeniuk O. Origin of the Ukrainian Church in America I O. Krawczeniuk [Електронний ресурс]. - Режим доступу: http: // theology.in.ua/en/index/monitoring/society_digest/61631// 17. 10. 14. 4. Kuropas M. The rest of the story // The Ukrainian Weekly. - 2006. - October, 1. - P. 7. 5. Paska W. Sources of Particular Law for the Ucrainian Catholic Church in the United States: A Dissertation Submitted to the Faculty of the Scool of Religious Studies of the Catholic University of America / Walter Paska. -Washington, 1975. - 183 p. 6. Pospishil V. J. Ex occidente lex. From the West - the law. The Eastern Catholic Churches under the tutelage of the Holy See of Rome / V. J. Pospishil. - N. Y. : St. Mary's religious action fund, 1979. - 164 p. 7. Procko B. The Byzantine Catholic Province of Philadelphia: A History of the Ukrainian Catholic Church in the U.S.A. Dissertation presented to the Faculty of Arts of the University of Ottawa throughthe Department of History as partial fulfillment of the requirements for the degree of Doctor of Philosophy / B. Procko. - Villanova, 1963. 8. Procko B. The establishment of the Ruthenian Church in the United States, 1884-1907 / Bohdan Procko // Pennsylvania history. - 1975. - 42. - P. 154. 9. Saint Stephen Byzantine Catholic Church Leisenring, PA. History [Електронний pecypc]. - Режсим доступy: http://www.archpitt.org/ component/ zoo/item/leisenringpa // 25.05.13. 10. Saints Peter and Paul Byzantine Catholic Church [Електронний pecypc]. Режим доступy: http://home.catholicweb.com/ ByzantinePunxy/ index.cfm/about // 02.06.14. 11. Saints Peter and Paul Byzantine Catholic Church Duquesne, PA History [Електронний ресурс]. - Режим доступу: http://www.archpitt.org/ component/zoo/item/duquesnepa 12. Slivka J. Historical Mirror Sources of the Rusin and Hungarian Greek Catholics in USA, 1884-1963. I J. Slivka. - Brooklyn, N. Y., 1978. - 342 p. 13. Warzeski W. Byzantine Rite Rusins in Carpatho-Ruthenia and America / Walter Warzeski. Pittsburgh: Byzantine Seminary Press, 1971. - 332 p. 14. Worth Parish history (1884-2010) // [Електронний pecypc]. - Режим доступy: http://www. transfiguration church shamokin.com/ history.htm125 // 19. 05. 2014. 15. Babiak A. Podvyh Mytropolyta Andreia Sheptytskoho yak Apostolskoho vizytatora dlia ukraintsiv (1920-1923) i yoho vzaiemyny z uriadom Polshchi / Avhustyn Babiak. - TrentoBoltsano, 2013. - c. 16. Bachynskyi Yu. Ukrainska immihratsiia $\checkmark$ Ziedynenykh derzhavakh Ameryky / Yulian Bachynskyi. T. 1. - Lviv, 1914. - 492 s. 17. Blazheiovskyi D. Beresteiska reuniia ta ukrainska istorychna dolia i nedolia. T. II: Kyivska Vselenska Tserkva v diaspori (1751-1988). / Per. z anhl. Lviv: Svichado, 2000. - 1148 s. 18. Vavryk V. Yepyskop Soter Ortynskyi Chyna Sviatoho Vasyliia Velykoho. U sorokalittia yoho smerty / Vasyl Vavryk. - Filadelfiia: Vydavnytstvo OO. Vasyliian u ZDA, 1956. - 75 s. 19. Vidozva do vsikh viddiliv P. N. Soiuza // Svoboda (SShA). - 1907. - 26 veresnia. - S. 1. 20. Kravcheniuk O. Stezhkamy Ottsia Ivana Volianskoho $v$ Amerytsi / Osyp Kravcheniuk. - Yorkton, 1981. - 85 s. 21. Mudryi S. Perekhid na inshyi obriad ( $z$ vizantiiskoukrainskoho na latynskyi) / Sofron Mudryi / per. z latynskoi movy o. Ivana Kozovyka. - Zhovkva: Misioner, 2013. - 228 s. 22. Na obezpechenie yzderzhekb pryvytaniia eho Preosv. S. Sot. Ortynskoho noveishe zhertvovaly // Svoboda (SShA). - 1907. 15 serpnia. - S. 1. 23. Ne buduite kaplyts! // Svoboda (SShA). 1896. - 9 lypnia. - S. 1. 24. Ofitsiinyi sait Rusynskoi HrekoKatolytskoi arkhyieparkhii Pitsburhu [Elektronnyi resurs]. Rezhym dostupu : http://www.archpitt.org/ // 24.01.14. 25. Proshchanie Ekstselentsii Andreia Sheptytskoho // Svoboda (SShA). - 1910. - 8 hrudnia. - S. 1. 26. Spomyny z davnykh lit // Svoboda (SShA). - 1912. - 5 veresnia. - S. 4. 27. Tsentralnyi derzhavnyi istorychnyi arkhiv Ukrainy u m. Lvovi ((TsDIAL Ukrainy), f. 358 (Sheptytskyi Andrei (Roman-MariiaOleksandr) (1865-1944), mytropolyt Halytskyi hrekokatolytskoi Tserkvy, hraf), op. 2, spr. 151 (Lysty sviashchenyka Yermi Karolia z Kanady i SShA do Sheptytskoho A.), 105 ark. 28. TsDIAL Ukrainy, f. 358 (Sheptytskyi Andrei (RomanMariia-Oleksandr) (1865-1944), mytropolyt Halytskyi hrekokatolytskoi Tserkvy, hraf), op. 2, spr. 178 (Lysty sviashchenykiv Kuziva Illi i Mykhaila do Sheptytskoho A.), 61 ark. 29. TsDIAL Ukrainy, f. 358 (Sheptytskyi Andrei (Roman-Mariia-Oleksandr) (1865-1944), mytropolyt Halytskyi hreko-katolytskoi Tserkvy, hraf), op. 2, spr. 85 (Lysty korespondentiv z prizvyshchamy na litery " $B$-Ya" zi SShA do Sheptytskoho A.), 97 ark. 30. TsDIAL Ukrainy, f. 358 (Sheptytskyi Andrei (Roman-Mariia-Oleksandr) (1865-1944), mytropolyt Halytskyi hreko-katolytskoi Tserkvy, hraf), op. 2, spr. 86 (Lysty sviashchenyka Kuryllo Kostiantyna z SShA do Sheptytskoho A.), 125 ark. 31. TsDIAL Ukrainy, f. 358 (Sheptytskyi Andrei (Roman-Mariia-Oleksandr) (1865-1944), mytropolyt Halytskyi hreko-katolytskoi Tserkvy, hraf), op. 2, spr. 230 (Lysty sviashchenykiv Oruna Zakhara i Pidhoretskoho Mykoly z Niu-Yorka do Sheptytskoho A.), 37 ark. 32. TsDIAL Ukrainy, f. 789 (Prystai Oleksa (1863-1944), hreko-katolytskyi sviashchenyk, misioner u SShA, tserkovnyi $i$ hromadskyi diiach), op. 1, spr. 7 (Spohady pro misionersku diialnist $v$ Amerytsi, lystuvannia z Bachynskym M., Okhrymovychem V., Sheptytskym A. ta in.), 151 ark. 